\title{
Contribution of Electrical Resistivity Tomography and Boring Technique in the Realization of Ten (10) Large Boreholes in a Crystalline Basement Rocks in the Centre-West of Benin
}

\author{
Nesny Yanonvoh Akokponhoué1,2,3, Nicaise Yalo², Bertrand Houngnigbo Akokponhoué1, \\ Rita Houngue ${ }^{2}$, George Agbahoungba ${ }^{1}$
}

\author{
${ }^{1}$ Chaire Internationale en Physique Mathématique et Applications (CIPMA Chaire UNESCO), Université d'Abomey-Calavi, \\ Cotonou, Benin \\ ${ }^{2}$ Laboratoire d'Hydrologie Appliqué, Institut National de l'Eau (INE), Université d'Abomey-Calavi, Cotonou, Benin \\ ${ }^{3}$ Société d'Ingénierie et d'Expertise (CANAL-EAU BENIN), Cotonou, Benin \\ Email: akoyaness@gmail.com, yalonicaise@yahoo.fr, akognibo1986@yahoo.com,hurita4@yahoo.fr, \\ agbahungbageorgr@gmail.com
}

How to cite this paper: Akokponhoué, $\mathrm{N}$ Y., Yalo, N., Akokponhoué, B. H., Houngue, R., \& Agbahoungba, G. (2019). Contribution of Electrical Resistivity Tomography and Boring Technique in the Realization of Ten (10) Large Boreholes in a Crystalline Basement Rocks in the Centre-West of Benin. Journal of Geoscience and Environment Protection, 7, 114-130 https://doi.org/10.4236/gep.2019.79009

Received: June 29, 2019

Accepted: September 21, 2019

Published: September 24, 2019

Copyright $\odot 2019$ by author(s) and Scientific Research Publishing Inc. This work is licensed under the Creative Commons Attribution International License (CC BY 4.0).

http://creativecommons.org/licenses/by/4.0/

(c) (i) Open Access

\begin{abstract}
In order to ensure access to drinking water for Benin populations by 2021, the Emergency Measure program for the reinforcement of the drinking water supply system of Savalou city was initiated in 2018. This program focuses on densification and extension of hydraulic infrastructures. Therefore, it is prominent to use rigorous approach for implementation and execution of drilling activities. The present work has the advantage of combining the use of electrical resistivity tomography and borehole technique to locate ten high flow drilling in Savalou city. The electrical resistivity tomography (ERT) panels were made based on the dipole-dipole arrays with 48 electrodes with $5 \mathrm{~m}$ inter-electrode spacing. The drilling was carried out over ten selected points and in two stages: confirmation test using piezometer and borehole diameter enlargement. Moreover, only piezometers with flow rate greater than $10 \mathrm{~m}^{3} / \mathrm{h}$ were enlarged. The tomography processing has identified 10 fractured zones that are defined by $250-1000 \mathrm{ohm} \cdot \mathrm{m}$ resistivity values and a width between 15 - $55 \mathrm{~m}$. The confirmation test carried out over ten piezometers exhibits high flow rates ranging from 9 to $35 \mathrm{~m}^{3} / \mathrm{h}$ with depths of 30 to $68 \mathrm{~m}$. Nine over the ten boreholes with a flow rate equal or greater than $10 \mathrm{~m}^{3} / \mathrm{h}$, have improved their flow rates by $50 \%$ to $100 \%$ after the boring technique. Thus, the cumulative flow rate has reached $252.7 \mathrm{~m}^{3} / \mathrm{h}$ for Savalou city and his surrounding areas.
\end{abstract}




\section{Keywords}

Boring Technique, Electrical Resistivity Tomography, Fractures, Savalou

\section{Introduction}

The southwestern region of the hills department is famous in Benin for its water supply problems because it is located on a portion made up only of crystalline rocks with slight alteration. Satisfying the water needs of local populations has been the concern of leaders either at the local or central level. The production of water for human consumption in the municipality of Savalou is ensured by the exploitation of surface water with machine installed since colonial times. On the basis of current annual population growth rate of $2.92 \%$ with $2.52 \%$ in 1970 (INSAE, 2016), the water demand has increased by a factor of three in a context of declining resource under effect of climate variability. To remedy this, the use of groundwater remains the main option to increase the existing flow rate of 150 $\mathrm{m}^{3} / \mathrm{h}$ (Maliki \& Tamadaho, 2012).

This alternative requires more serious methodology in the study of implementation and execution of drilling work in a context where $70 \%$ of geophysical prospecting work proved unsuccessful after drilling. Geophysics especially electrical resistivity tomography (ERT) is a highly recommended tool for groundwater prospecting in basement areas (Alle et al., 2018). This method determines with a better precision, the exact position of the geological discontinuities and locates the areas of high hydrogeological interest (Vouillamoz et al., 2015; Soro et al., 2017; Alle et al., 2018). The purpose of this work is in one hand the use of electrical resistivity tomography (ERT) to determine potential fractured aquifers and the borehole technique on the other hand to achieve ten (10) large boreholes in the municipality of Savalou.

In contrary to previous work, the present one does not stop only at positioning drilling points but also achieve borehole realization for confirmation of position selected.

\section{Geographical, Geological and Hydrogeological Contexts}

Located in the south-west of the department of hills, the study area is located between latitude $7^{\circ} 35$ and $8^{\circ} 13$ North and longitude $1^{\circ} 30$ and $2^{\circ} 6$ East. It shares its borders with the municipalities of Dassa-Zoumè and Glazoué in the East; Djidja in the South, Bantè in the North and Republic of Togo in the West for about $65 \mathrm{~km}$ north-south boundary (Figure 1). It long of about $58 \mathrm{~km}$ from west to east and covers an area of $2674 \mathrm{~km}^{2}$; which represents $2.37 \%$ of the national territory with a total population of 144,814 inhabitants (INSAE, 2016).

Geomorphologically, there is a very rugged peneplain with isolated domes of inselbergs and small chains, the longest stretches for about $20 \mathrm{~km}$ and picturesque hills. The relief culminates between 120 and $500 \mathrm{~m}$ with slopes varying 


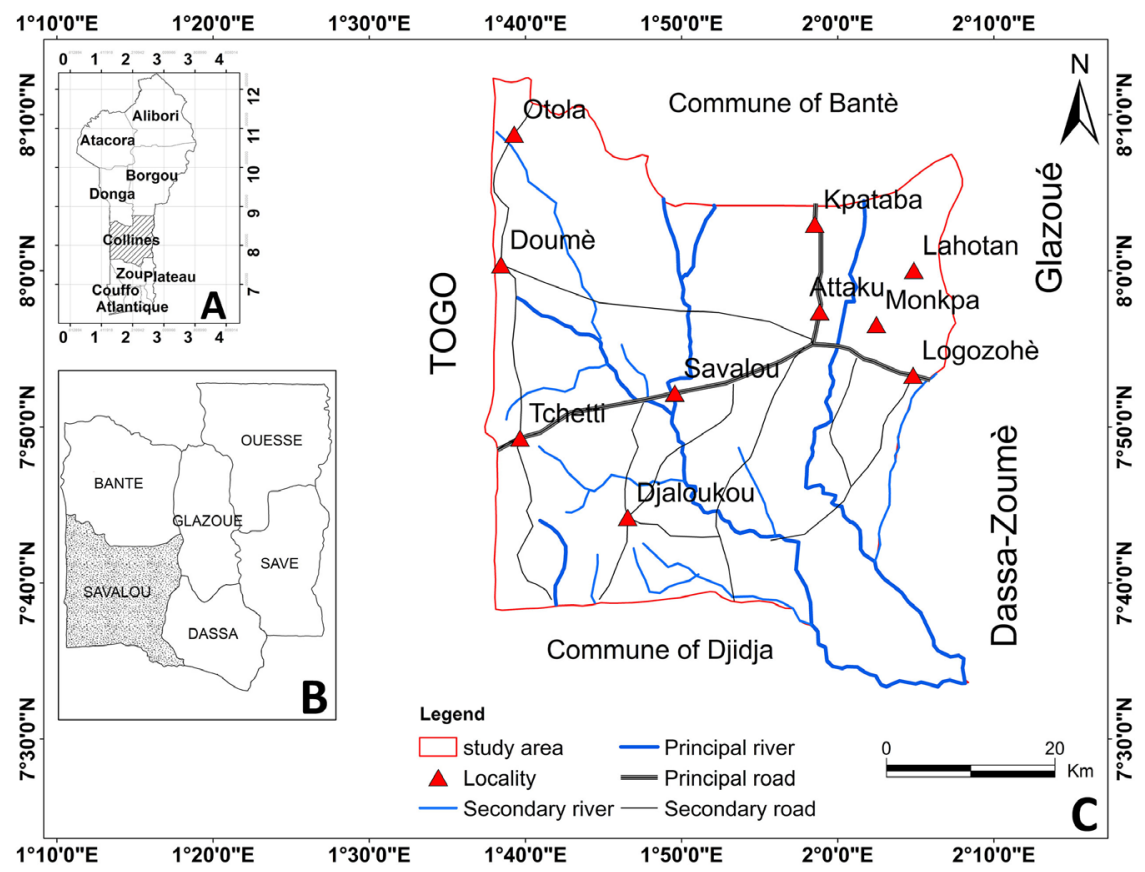

Figure 1. Location of the study area (source: Fonds topographique IGN 2002).

between $3 \%$ and $10 \%$ in the agglomerated sites. It largely determines the ability of runoff, infiltration and evaporation. It is an eroded plain developed on gneiss and leaving in relief the granite elements or ferruginous carapaces the most resistant.

Geologically, the area lies on a subsoil composed of crystalline rocks with low alteration (10 $\mathrm{m}$ on average) and based on Precambrian material from the old granitic-gneiss basement. Affaton (1987), Boukari (1982), and Adissin-Glodji (2012) showed the geological complexity of this area. It is indeed a lithological and structural ensemble that has undergone several phases of deformation, metamorphism and magmatism. Bietite and/or porphyry granites are found in Chetti, biotite and/or amphibole gneisses of Dagadoho, biotite and hyperthermic granulite gneisses of Monkpa and blastomylonites and mylonites related to the Kandi accident. These various geological phenomena are materialized by numerous fractures generally structured N-S and E-W and giving rise to the principal rivers in the area (Figure 1). The most representative of these fractures is the Kandi fault, $25 \mathrm{~km}$ wide and crossing the entire study area from north to south.

At the hydrogeological level, this area is characterized by the coexistence of two superimposed reservoirs. It is the case everywhere in the crystalline basement zone in Benin. These are reservoirs of saprolite and fracture, also called discontinuous aquifers. Though the tanks of saprolite have a primary porosity and a capacitive role because of their sandy-clay nature, the fracture reservoirs are underlying with secondary porosity fractures playing a transmissive role. The study zone therefore has a double porosity/double permeability due to the presence of a matrix of high porosity with low permeability, and a fractured zone of 
high permeability with low porosity Kamagate (2006). The results of numerous drilling carried out by the Village Hydraulic projects in the area show that the alterite reservoir has a very small thickness that is between 5 and $10 \mathrm{~m}$ with drilling depths ranging from 38 to $80 \mathrm{~m}$, for flows between 0.7 at $10 \mathrm{~m}^{3} / \mathrm{h}$. The success rate for boreholes is $30 \%$ to $70 \%$ for village water supply and $20 \%$ to $30 \%$ for urban water (high flow) supply.

\section{Materials and Methods}

\subsection{Data and Equipment Used}

The data used in this work consist of ten ERT panels made on previously selected sites following the extraction of lineaments by remote sensing, the results of which are not presented in this paper. The tomography work was done in the months of June and July 2018. The survey equipment of the ERT for field data collection, is composed of a Syscal R2 with Swicth 48 from the company Iris Instruments, with its accessories (connection coils or flutes, electrodes, a hectometer, weights, a compass, a GPS, crocodile clips, a DC/DC voltage converter, a 12 $\mathrm{V}$ battery etc.). The geophysical data processing was performed by the software provided with the equipment such as Prosys II, X2IPI and DC2DInv Res.

On behalf of the drilling work, the data used are summarized in cuttings, depth drilled, water inflows and flows. The drilling equipment is TH5 (for FORATEC Society) drilling machine that can work rotary and Hammer Bottom Hole (MFT) with accessories (tricome, trilame, MFT, rods...) brand Canadian perfectly adapted to the context of the study area.

\subsection{Methods}

\subsubsection{Geophysical Prospection Technique}

The sites prospected by the electrical resistivity tomography (ERT) were retained after a preparatory work. First of all, examination of the data related to the work of extractions of lineaments by remote sensing. In addition, analysis of $1 \mathrm{D}$ electrical survey the results were carried out. Both analyses were conducted in order to detect the anomalies previously noted by the drag which results are not presented in this paper. These data, grouped and analyzed, made it possible to define the potential sites of hydrogeological interest. The ERT has complemented this work in order to implement future drilling with certainty and increase the probability of success of new hydraulic structures. Indeed, the ERT makes it possible to image properties of a medium from a series of measurements carried out around and inside it (Descloitres et al., 2008; Soro et al., 2017; Alle et al., 2018). Applied geophysical methodology consists of measuring the physical parameters of the subsoil from the surface. That of the tomography of electrical resistivities corresponds to a succession of electrical soundings and electric tracks made next to each other. It therefore requires a large number of electrodes connected to a multicore cable.

The Syscal R2 (resistivity meter) is able to select the electrodes used for the 
current injection and the measurement of the potential difference in a predefined sequence. For the investigation of the field work of this study, the mode of data acquisition is programmed according to the dipole-dipole configuration. Indeed, the work of several authors (Baltassat et al., 2017; Roques, 2013; Alle et al., 2018) have shown that the dipole-dipole (DD) configuration offers good resolution of subsurface terrains and vertical and horizontal discontinuities.

The data acquisition sequences are programmed under the Prosys II software. Field investigations are made with $240 \mathrm{~m}$ profiles for an inter-electrode distance of $5 \mathrm{~m}$, i.e. 48 electrodes in total. The 10 electrical panels are implemented on 10 sites selected according to their hydrogeological potential. The measurement parameters (number of repetitions (stacks), injection time, acceptable error, measurement mode) are previously defined and stored in the syscal. The measurements of the profiles are filtered and processed under the X2ipi software, then inverted with the Res2dInv software while integrating the topography along the profiles. For a good comparison of the different electrical panels, it was chosen and applied a color scale for the different ranges of resistivity (between 5 and $4000 \mathrm{Ohm} \cdot \mathrm{m})$ to the whole of the high definition imaging of the subsoil in the study area.

\subsubsection{Aquifer Capture Technique}

The execution of the drilling was done in two phases: a confirmation survey and a boring technique. In the study area, the drilling takes place on each site in the soft terrains of the alteration regions and in the hard ground of the crystalline basement rocks. The method of drilling execution was thus in two stages and presented as follows.

\section{a) Rotational drilling in alterations}

The first geological formations crossed are the saprolite with a small thickness ( 2 to $10 \mathrm{~m}$ ). For this reason, the drilling in these saprolites is made with the rotary tricone of $9^{17 / 8}$ which is $267 \mathrm{~mm}$ with compressed air to the roof of the unweathered rock. The tricone is rotated from the soil surface by a string of stems. The equipment sinks into the ground by abrasion, rotation and thrust. Extraction of cuttings from the hole is made continuously by circulation of the compressed air which brings them up to the surface. Cuttings removal is necessary to know the nature of the rocks crossed. At the end, the tricone is removed and temporary tubes are inserted along the entire alteration to maintain the walls intact.

b) Hammer drilling in the hard ground of the unweathered rock

After installation of the temporary tubes, drilling is continued with another hammer drill tool of $6 " 1 / 2(176 \mathrm{~mm})$ until the favorable aquifer zone recommended by hydro geophysical studies is reached. The tool is set in rotation and percussion to break and grind the rock of the drilled ground. During drilling, the air flow allows blow-evacuation up the cuttings of the terrain crossed by the annular space on the surface. These cuttings are taken at each change of rod by a shovel just after they are removed from the borehole. The cuttings are sampled per meter in boxes for visualization to define the geological section. During the 
drilling, the inflows of water indicating wet fractures are visible (rising water + cuttings) and quantifiable. Generally, water inflow is progressive. In fact, crossing a major fracture well fed causes a significant increase in flow. The estimation of discharge at each water flow and its depth is very essential. It helps to decide on the continuation or the stop of the drilling. Discharge computed is a volumic discharge based on Equation (1):

$$
Q=\frac{V}{t}
$$

where $V$ is water volume in time $t$. Confirmation survey is positive ready for boring, when its cumulative flow at the end of drilling is equal to or greater than $10 \mathrm{~m}^{3} / \mathrm{h}$. In this case, the temporary tubes are left in place and well protected for the second phase, which is the boring of the initial drilling diameter.

\section{c) Drilling bore execution}

The boring technique is almost the same as the borehole technique. Once the survey is positive, you have to go back and bore the borehole. It consists of removing the initial temporary tubes and taking over the drilling with tools (hammer and tricone) for much more diameters. The rotary bore in soft ground is made with a $15^{\prime \prime}$ tricone. Thus, the diameter passes from $9^{17 / 8}$ to $15^{\prime \prime}$. Once the roof of the unweathered rock is reached, a temporary tube is always laid and the drilling in the hard ground follows with hammer drill with 10" diameter. The drilling engineer must ensure that the pushed/rotated torque is properly adjusted to have a steady and constant progression of the cutter. Every $40 \mathrm{~cm}$, the hole is cleaned by blowing and or sweeping along the stem to evacuate the cuttings and to avoid any jamming of the initial hole. At this stage, the influx of water, its depths, and flows are followed and well noted. It should be noted that the flow rate here can double or triple or more at each corresponding waterfall depending on the nature of the rock and the fracture. Discharge computation is the same as previously. In the case, most productive fractures are on the surface, there is no need of continuing the boring at the risk of losing the flow in the dry underlying fractures that absorb water from above.

\section{d) Drilling equipment}

The most delicate step in the process of performing water drilling is the equipment. Caption plan especially the position of the strainered tube influence the flow. The plan is proposed by mutual agreement between the driller and the hydrogeologist in charge. As soon as, the drilling plan is set up (tube type, length and position according to geological structures) they are aligned on the ground for verification. The caption column diameter is of $178 / 195 \mathrm{~mm}$. Strainered tubes are placed in front of water inflow along 3 to 8 meters depending on the depth of the different fractures crossed. The base of the column is obstructed by an unstrainered tube that serves as a decanter. The tubes must get down freely under its own weight into the hole if the drill is well straightened. Otherwise, the driller must remove the tube and bore back (Drouart \& Vouillamoz, 1999). An above ground of at least $0.5 \mathrm{~m}$ must be provided based on the topographic. After all, filtration layer (calibrated gravel of about 1 to $3 \mathrm{~mm}$ diameter) is set up. 


\section{e) Gravelling}

Before placing the filtration layer (gravel), the volume of gravel VG to be used is calculated. This computation is made according to the empirical Equation (2) of the filtering mass used by Drouart \& Vouillamoz (1999).

$$
V G=h \times 0.8 \times\left(D^{2}-d^{2}\right)
$$

With $V G$ the volume of filtering massive in (Liter),

$h$ the height (dimension) of the filter bed in (m),

$D$ the diameter of the hole bored in (inches),

$d$ the diameter of the tubes in (inches).

Once $V_{G}$ is computed, the graves are inserted into the peri-annular space that is between the tube and the walls of the ground. Gravel insertion has to be progressive and soft in order to avoid trapping which forms obstacles (bridge or bloc) in the annular space. However, in such conditions, tapping the tube column or inflow of under pressured water is necessary to break the bridge. At the end of the graveling process, measurements are made to ensure that the expected gravel dimension is reached. The remaining annular space is filled over two (2) meters with coarse sand, and the rest by the cuttings up to five (5) meters from the topographic surface. Then, the five meters remaining after the development (cleaning) of the borehole is cemented in order not only to maintain the tube column but also to protect the bore against possible pollution from the surface.

\section{f) Drilling development}

The development of drilling is pneumatic i.e. air lift, it is an operation that consists of sending compressed air into the borehole by galvanized pipes of diameter $1 " 1 / 2$ up to 1 meter from the bottom of the borehole through which the water flows to the surface. The pressure of the air sent is progressive in order to allow a correct rearrangement of the filtering mass. The development is continued until clean water without sand particles or rock debris or cuttings is obtained. It is confirmed by a control of the sand content by the sand spot method observed in a 10-liter bucket. At the end of the development, the pipe head is closed by a lockable metal before pumping test. The overall methodology used is summarized on Figure 2.

\section{Results}

\subsection{Electrical Resistivity Tomography}

The length of the profiles is $240 \mathrm{~m}$, and each profile is positioned in a direction that allows crossing major lineament more or less perpendicularly. Center of measurement on profile has to coincide with the deflection zone.

\subsubsection{P1 Profile of Monkpa}

The P1 profile of Monkpa was made in the direction E-W and secant at the major lineation (L1MP) of the zone. High definition imagery results of inversion shows good mathematical convergence. The analysis of the imagery shows three layers: 


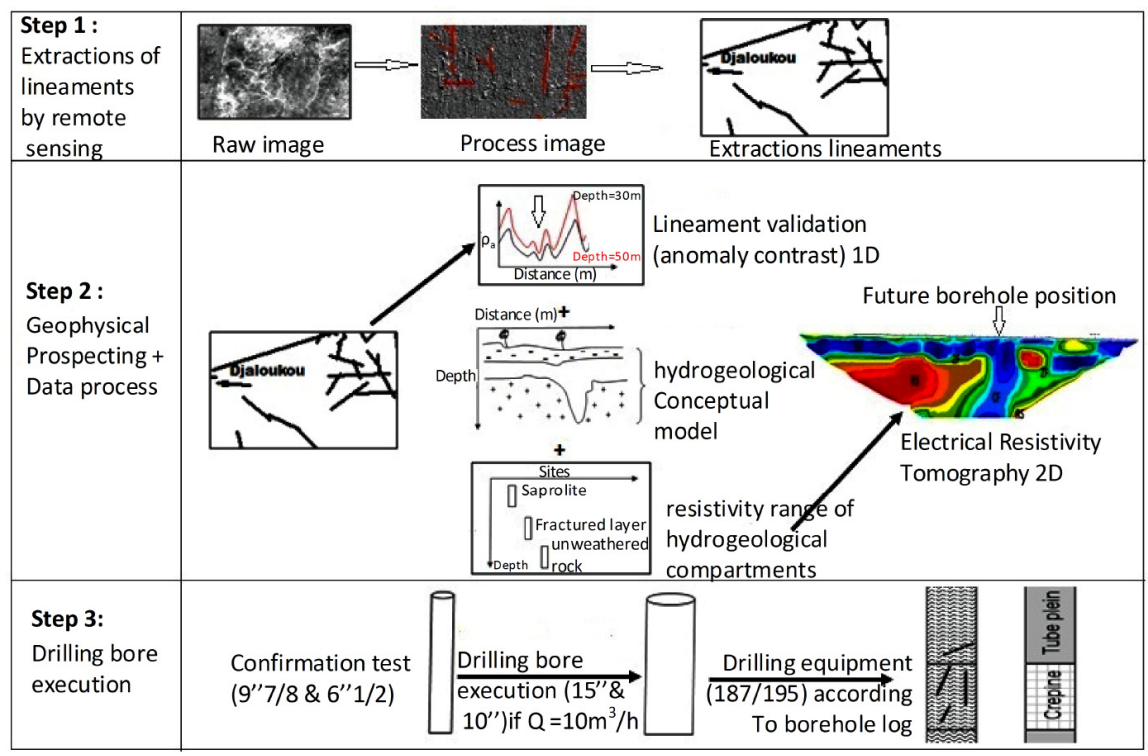

Figure 2. Methodological approach used in the study.

- A surface layer (dark blue to light blue in Figure 3) conductive with resistivity ranging from 10 to $100 \Omega \cdot \mathrm{m}$. The thickness of this layer is very variable, averaging about $6 \mathrm{~m}$ along the profile, it is deep and reaches $30 \mathrm{~m}$ between the abscissa $\mathrm{X}=75$ and $\mathrm{X}=125 \mathrm{~m}$ of the profile. This layer dipped under a thin, more resistant layer (lateritic shell) in the west in profile. This first layer corresponds to the more or less clayey saprolite.

- A layer (from green to yellow in Figure 3) resistivity ranging from 100 to 850 $\Omega . \mathrm{m}$ in general with a thickness of about $35 \mathrm{~m}$. This layer is very thin approximately $3 \mathrm{~m}$ between the abscissa $\mathrm{X}=75$ and $\mathrm{X}=125 \mathrm{~m}$ of the profile. This second layer represents the cracked zone of the rock.

- In deep region of about $40 \mathrm{~m}$ between abscissa $\mathrm{X}=80$ and $\mathrm{X}=160 \mathrm{~m}$ profile, appears a layer with very high resistivity values greater than $4000 \Omega \cdot m$ that corresponds to the healthy crystalline base. This third layer which is the unweathered rock is more superficial ( $8 \mathrm{~m}$ from the surface) to the east of the profile. The discontinuity between the abscissa $\mathrm{X}=75$ and $\mathrm{X}=125 \mathrm{~m}$ could be interpreted as a probable deflection related to a fracture of tectonic origin which favored the development of an alteration and a thicker fissured zone at this place thus creating a favorable situation for the implantation I1 of a future water point (drilling) at the abscissa $\mathrm{X}=115$ of the profile.

\subsubsection{Profiles P7, $\mathrm{P} 4$ and $\mathrm{P} 10$}

The high definition imagery of the P7, P4 and P10 profiles made perpendicularly to the major lineaments (L13Ba1, L17Ba2 and L3Sj) respectively at Base-Colas 1 (Figure 4), Base-Colas 2 (Figure 5) and Sohèdji (Figure 6) inversions results show good mathematical convergence. The distribution of the electrical resistivity on each panel has almost the same characteristics as result of the Monkpa P1 profile. Thus, the same interpretation is proposed. 
P1 Monkpa

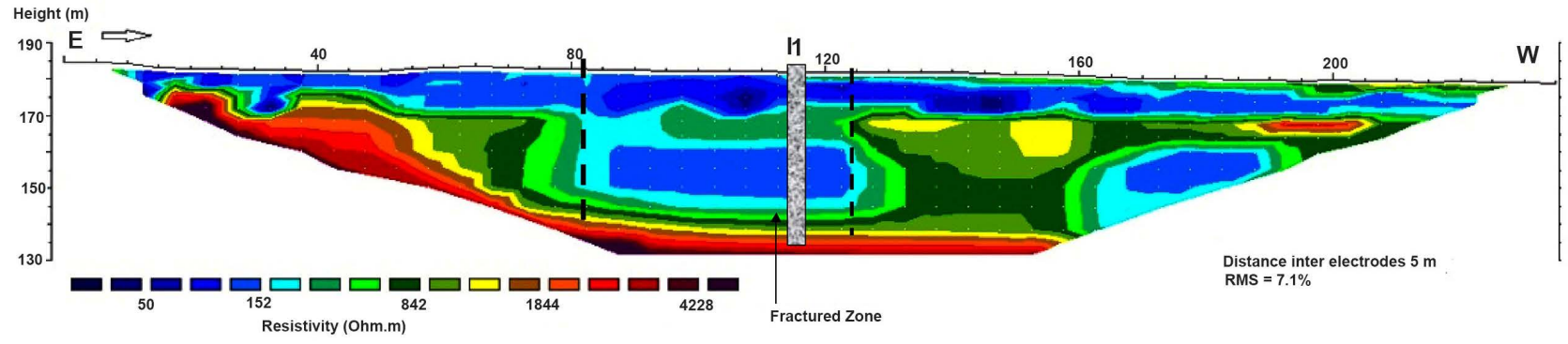

Figure 3. High resolution imagery of profile P1 at Monkpa.

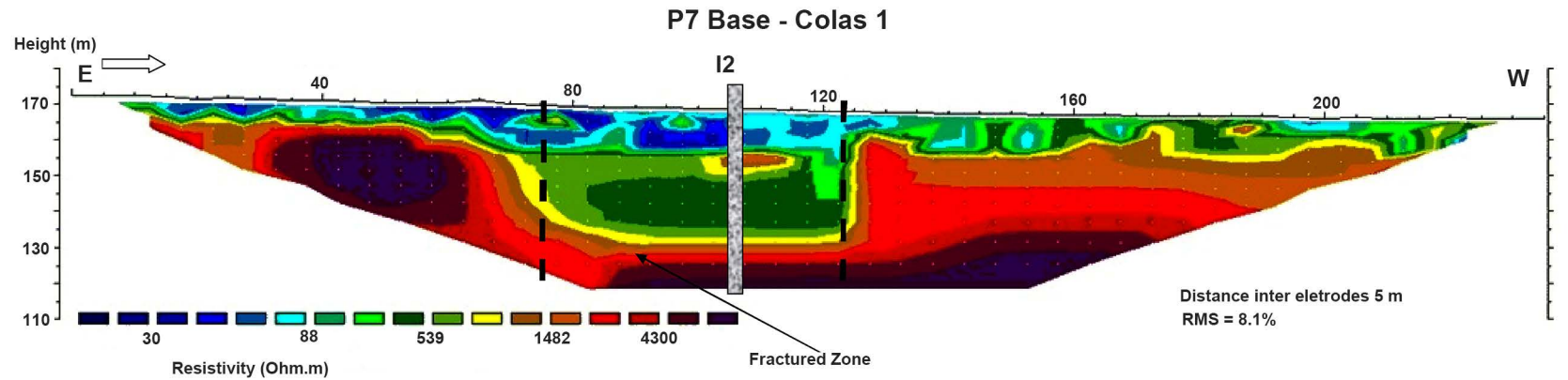

Figure 4. High resolution imagery of profile P7 at Base colas 1 (Savalou).

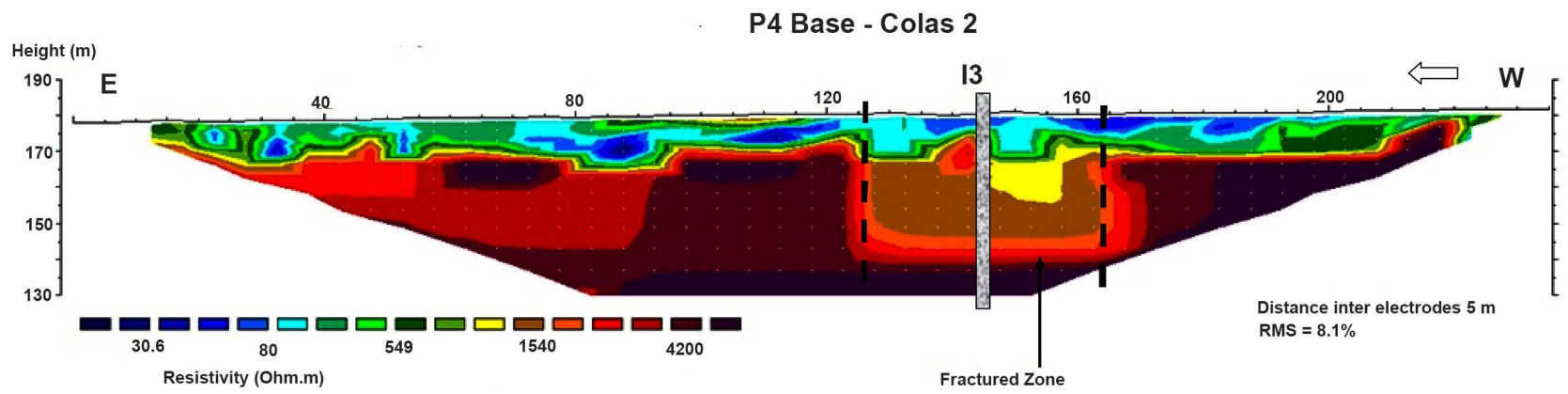

Figure 5. High resolution imagery of profile P4 at base colas 2 (Savalou).

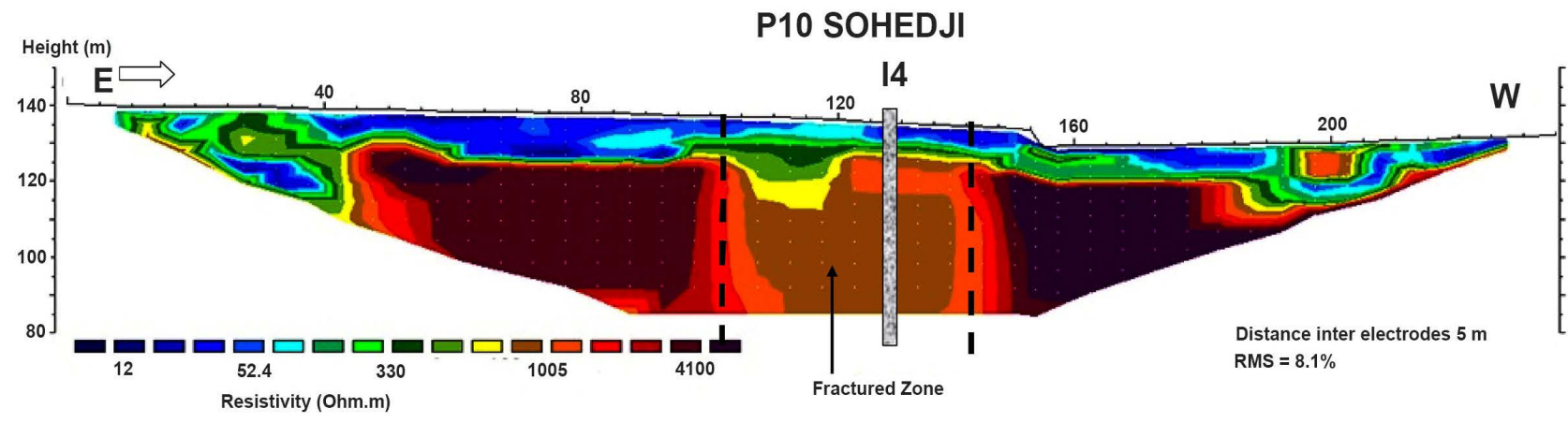

Figure 6. High resolution imagery of profile P10 at Sohèdji.

- A superficial horizontal layer along P7, P4 and P10 is of variable thickness with average value of about $8 \mathrm{~m}$. In addition, the electrical resistivity ranges from 10 to $50 \Omega \cdot \mathrm{m}$ for the profile 7 , from 10 to $40 \Omega \cdot \mathrm{m}$ for the profile 4 and 
from 10 to $60 \Omega \cdot \mathrm{m}$ for the profile 10 . These resistivity values correspond most likely to saprolites that are clayey and saturated with water (from dark blue to light blue).

Below is a relatively resistant layer of 50 to $800 \Omega \cdot \mathrm{m}$ for the profiles P7 and $\mathrm{P} 4$ whereas it is of 60 to $1000 \Omega \cdot \mathrm{m}$ for the profile P10. These resistivity values are relative to the fractured rocky zones. The thickness of this second layer is about $5 \mathrm{~m}$ except for the right deflections where they deepen. These high depths are noted between abscissas $\mathrm{X}=75$ and $\mathrm{X}=125$ for profile $\mathrm{P} 7$ and between abscissa $\mathrm{X}=125$ and $\mathrm{X}=162$ of profile $\mathrm{P} 4$ and between abscissa $\mathrm{X}=$ 110 and $\mathrm{X}=135$ of Profile P10.

- Finally the third very resistant layer, resistivity greater than 1500 S.m, appears at $12 \mathrm{~m}$ depth and has discontinuity locally within it. These discontinuities result in a deepening of the conductive zone (fractured zone) up to $35 \mathrm{~m}$ with a width of $55 \mathrm{~m}$ for profile $\mathrm{P} 7$ and a width of $35 \mathrm{~m}$ for profile P4, Nevertheless, for the profile P10, the lower limit of the discontinuity is not perceived by the electrical panel. However, its width is $20 \mathrm{~m}$.

As with the high definition imaging of the Monkpa P1 profile, each discontinuity observed here could also be interpreted as a probable deflection related to a fracture of tectonic origin that favored the development of an alteration and a thicker fissured zone. This gives a favorable situation for the implantation of future water points (drilling) I2; I3; I4 at abscissa $\mathrm{X}=115, \mathrm{X}=140$ and $\mathrm{X}=130$ respectively on the $\mathrm{P} 7$ profile at Base-Colas1, the $\mathrm{P} 4$ profile at Base-Colas2 and the P10 profile at Sohèdji (Figures 4-6).

Since we cannot present the high-definition imagery of the ten (10) profiles produced for this paper, we only hold four (4). However, the characteristics of the ten panels made are showed forward.

\section{Hydrogeological Interpretation of Geophysical Models}

The hydro-geophysical approach consists of transformation of geophysical models into hydrogeological ones. Thus, a hydrogeological interpretation of the high-definition imagery of the different electrical panels of the ERT is done. One aspect of this study was to correlate the geophysical parameters (resistivity) with the different components of soil. The high definition imagery of each of the ten profiles provides the following information: 1) the presence of an alteration thickness that varies from $7 \mathrm{~m}$ (profile 13) to $20 \mathrm{~m}$ (profile 9), 2) a fracture zone that results in a well-developed weathered cracked zone and 3) the unweathered rock where is located probable faults which allowed the deepening of the altered cracked zone. The results show that the geophysical model in area study is: 10 to $150 \mathrm{Ohm} \cdot \mathrm{m}$ for saprolite, 250 to $1000 \mathrm{Ohm} \cdot \mathrm{m}$ for fractured zone and 1000 to $4000 \mathrm{Ohm} \cdot \mathrm{m}$ for hard rock (unweatherd rock). Following the hydrogeological interpretation, points with high potentialities were identified and their characteristics are summarized in Table 1.

Firstly, the analysis consisted in comparing the average values of the thicknesses of saprolite, the thickness of cracked zone and the extension of the 
Table 1. Summary of the results and interpretation of the ten panels: Comparison of the favorable points. In green the best values; in yellow the intermediate values in red the worst values of each parameter.

\begin{tabular}{ccccccc}
\hline $\begin{array}{c}\text { Prospective } \\
\text { water point }\end{array}$ & $\begin{array}{c}\text { Distance on } \\
\text { profil }(\mathrm{m})\end{array}$ & $\begin{array}{c}\text { Fracture zone } \\
\text { resistivity }(\Omega \cdot \mathrm{m})\end{array}$ & $\begin{array}{c}\text { Saprolite } \\
\text { thickness } \\
(\mathrm{m})\end{array}$ & $\begin{array}{c}\text { Faults } \\
\text { thickness } \\
(\mathrm{m})\end{array}$ & $\begin{array}{c}\text { Fracture } \\
\text { extension } \\
(\mathrm{m})\end{array}$ & $\begin{array}{c}\text { Fractures } \\
\text { direction }\end{array}$ \\
\hline MpP1I1 & 115 & 350 to 850 & 10 & 40 & 40 & N10 \\
Ba1P7I2 & 120 & 300 to 700 & 08 & 30 & 55 & N40 \\
Ba2P4I3 & 140 & 300 to 800 & 06 & 03 & 35 & N20 \\
SjP10I4 & 130 & 400 to 1000 & 08 & 03 & 20 & N44 \\
Sg2P3I5 & 125 & 250 to 600 & 15 & 06 & 45 & N10 \\
Dh1P6I6 & 110 & 300 to 850 & 15 & 08 & 15 & N40 \\
Dh2P13I7 & 115 & 350 to 700 & 07 & 05 & 30 & N20 \\
KsP9I8 & 135 & 400 to 1000 & 20 & 30 & 20 & N40 \\
AjP2019 & 105 & 250 to 800 & 10 & 12 & 35 & N45 \\
HnP15I10 & 125 & 300 to 850 & 08 & 15 & 50 & N15 \\
\hline
\end{tabular}

fracture of the ten profiles. The electrical resistivity ranges of the different fracture zones on each profile are good for carrying out positive drilling and correspond to the results of Alle et al. (2018). A local comparison of the different future water points, which are all considered favorable, shows that:

- Implantations I1, I5, I6, I8 and I9 have in average the thicknesses of the most acceptable saprolite $(15 \mathrm{~m})$ which ensure the storage function, and relatively acceptable lateral extensions (30 $\mathrm{m}$ in average) except I6 which only have 15 $\mathrm{m}$ extension. Apart from I1, the thickness of the crack zone is very small for the four other implantations. For these five locations, the dimensions of the tanks are generally the most convincing for obtaining large boreholes.

- Implantations I2, I4 and I10 have a thickness of average saprolite ( $8 \mathrm{~m})$ with the best lateral extension of fracture of $(55 \mathrm{~m})$ for I2, $(50 \mathrm{~m})$ for I10 and average $(20 \mathrm{~m})$ for $\mathrm{I} 4$. As for the altered fissured zone, it is acceptable $(30 \mathrm{~m})$ for I2, average $(15 \mathrm{~m})$ for $\mathrm{I} 10$ and poor $(3 \mathrm{~m})$ for I4.

- Implantations I3 and I7 have the thicknesses of the weakest saprolite (6 m) with good lateral extensions. These two sites have very low altered fissured areas $(4 \mathrm{~m})$ on average.

- Implantations I2, I4, I6 and I8 are on fracture directions, which is according to the instructions to Achidi et al. (2012), are the most productive. As for the implantations I1, I3, I5, I7 and I10 they are on compression directions. Thus, they are not so much favorable to the realization of drilling.

Therefore, these future water points may be classified in priority order as I1, I2, I8, I9, I5, I4, I6, I7, I3 and I10

\section{Analysis of the Signatures of High-Flow Drilling}

After ERT work, interpretation of the results and prioritization of future water 
point locations, the work of completing the ten (10) holes followed.

\section{- Drilling F6}

Monkpa drilling (F6Mp): $47 \mathrm{~m}$ deep, it was carried out on biotite gneiss over $5.02 \mathrm{~m}$ at the tricone corresponding to the thickness of the alteration (TA) and $41.98 \mathrm{~m}$ at the bottom of the hole (MFT) corresponding to the thickness of the drilled plinth of which $37.98 \mathrm{~m}$ in the altered fissured zone (AFZ). Two (2) water inlets were crossed respectively at 35 and $40 \mathrm{~m}$ depth for a cumulative flow of 10 $\mathrm{m}^{3} / \mathrm{h}$ during prospection and $10.5 \mathrm{~m}^{3} / \mathrm{h}$ after drilling and equipment with a water column of $27 \mathrm{~m}$. The technical and lithological structure of the Monkpa drill is shown in Figure 7. A single strainer of $6 \mathrm{~m}$ was used to capture the two water inflow (WI).

\section{- Drilling F1}

The drilling of Base Colas 1 (F1Ba1): from a depth of $55 \mathrm{~m}$, it is carried out on hyperstene gneiss with $5.25 \mathrm{~m}$ tricone corresponding to the thickness of the alteration (TA). The thickness of the base drilled with MFT is $49.75 \mathrm{~m}$, of which $46.75 \mathrm{~m}$ is for the altered fissured zone (AFZ). Two (2) entrances of water are crossed respectively at 23 and $45 \mathrm{~m}$ of depth for an accumulated flow of $10 \mathrm{~m}^{3} / \mathrm{h}$ during the confirmation survey and of $25 \mathrm{~m}^{3} / \mathrm{h}$ after boring and equipment with a water column of $48 \mathrm{~m}$. Figure 8 illustrate the lithological section and the column capturing the drilling carried out at Base Colas1. Two strainers of $6 \mathrm{~m}$ are used and placed in front of water inflow (WI).

The summary of the work carried out on the ten (10) confirmation surveys considered in this paper is presented in Table 2.

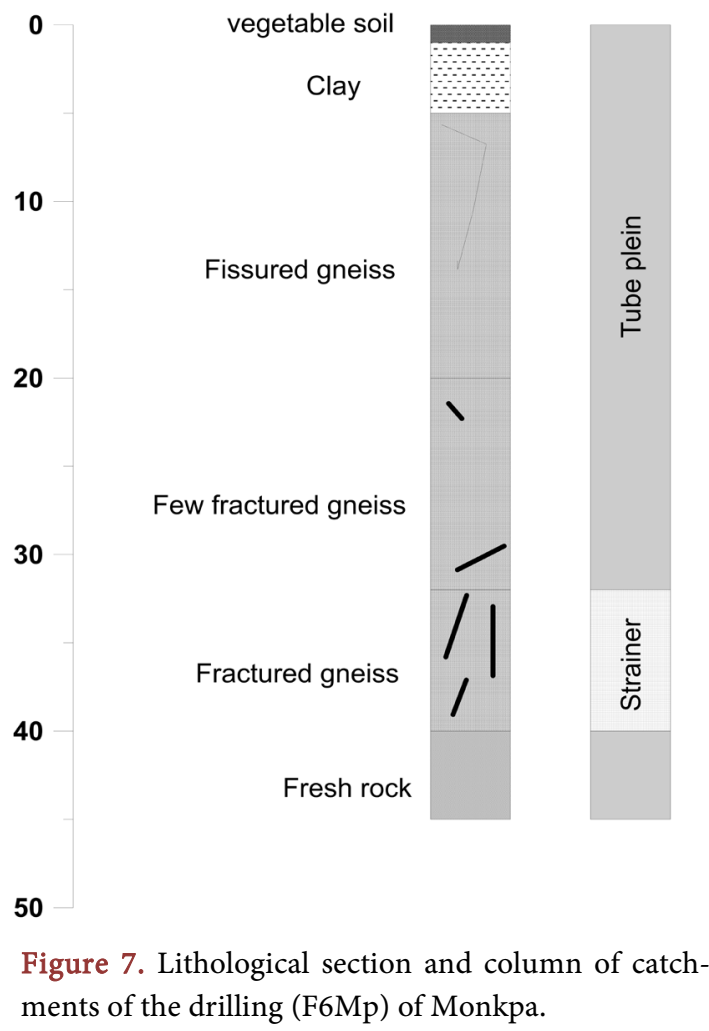




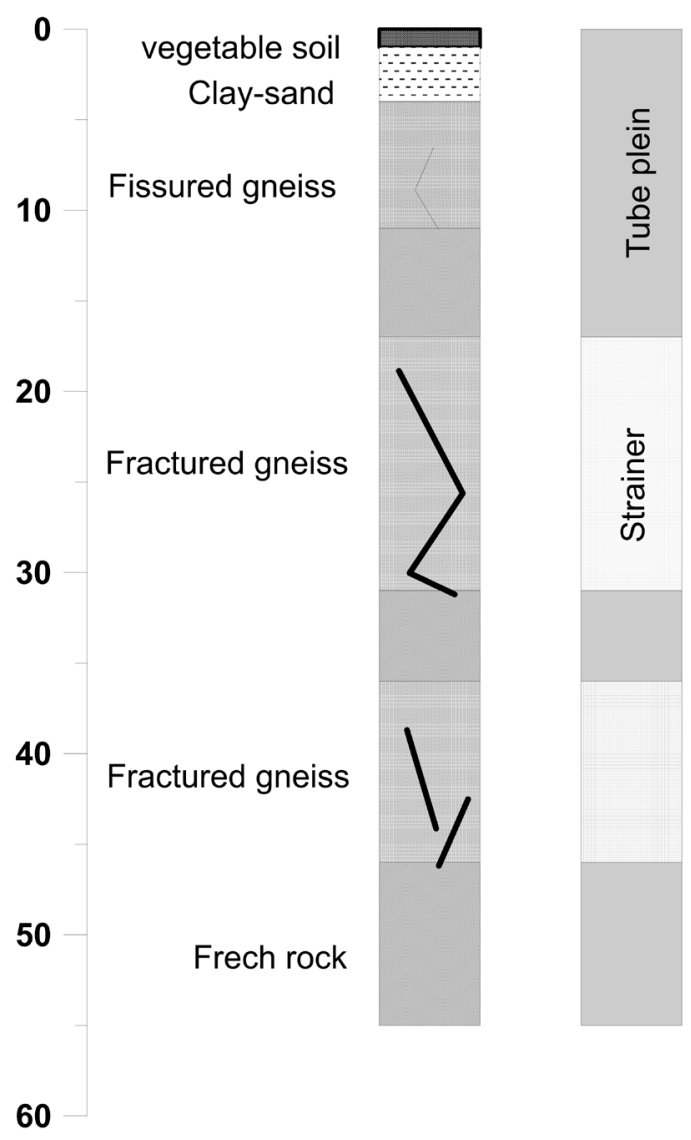

Figure 8. Lithological section and column of catchments of the drilling (F1Ba1) of Base Colas1.

Table 2. Location and characteristics of the ten (10) confirmation surveys.

\begin{tabular}{|c|c|c|c|c|c|c|c|c|}
\hline \multirow{2}{*}{ Forage } & \multicolumn{2}{|c|}{ Coordinates } & \multirow{2}{*}{$\begin{array}{l}\text { Depth } \\
\text { (m) }\end{array}$} & \multirow{2}{*}{$\begin{array}{l}\mathrm{TA} \\
(\mathrm{m})\end{array}$} & \multirow{2}{*}{$\begin{array}{c}\text { AFZ } \\
(\mathrm{m})\end{array}$} & \multicolumn{2}{|c|}{ Depth (m) } & \multirow{2}{*}{$\mathrm{Q}\left(\mathrm{m}^{3} / \mathrm{h}\right)$} \\
\hline & $\mathrm{X}$ & $\mathrm{Y}$ & & & & $\mathrm{WI}_{1}$ & $\mathrm{WI}_{2}$ & \\
\hline F1 Ba1 & 1.94973 & 7.92037 & 55 & 5.25 & 46.75 & 23 & 45 & 10 \\
\hline $\mathrm{F} 2 \mathrm{Ba} 2$ & 1.9661 & 7.9140 & 48.8 & 5.03 & 37.4 & 30 & 42 & 12.3 \\
\hline$F 3 A j$ & 1.87464 & 7.95643 & 55 & 3.76 & 47.77 & 33 & 45 & 15.3 \\
\hline $\mathrm{F} 4 \mathrm{Sg} 2$ & 1.9272 & 7.8311 & 30 & 4.51 & 22.68 & 26 & - & 22.6 \\
\hline F5Sj & 1.93468 & 7.85005 & 36 & 4.8 & 28 & 21 & - & 24 \\
\hline F6Mp & 2.04166 & 7.90053 & 47 & 5.02 & 37.98 & 35 & 40 & 10 \\
\hline F7Dh1 & 1.93086 & 7.85800 & 35 & 5.35 & 24.65 & 20 & 26 & 35 \\
\hline F8Dh2 & 1.92760 & 7.90588 & 68.4 & 5.3 & 48 & 36 & 46 & 13 \\
\hline F9Ks & 2.0151 & 7.8850 & 30.4 & 6.2 & 20 & 18 & - & 11 \\
\hline F10Hn & 1.9001 & 7.8441 & 63 & 4.8 & 46.5 & 32 & - & 9 \\
\hline
\end{tabular}

The ten drill holes (confirmation surveys) are described in detail in Table 2. We emphasis on the variations of the depths, the inflow of water and the flow rates obtained during the final drilling. The analysis of the table reveals that in 
the study area, the rock (Gneiss) is altered up to $5 \mathrm{~m}$ deep, followed by fissured and fractured gneiss over thickness varying from 20 to $47 \mathrm{~m}$ depth. The healthy gneiss appears at some points, showing local fractures of few centimeters thickness until the end of drilling. Drilling depths vary between 30 and $63 \mathrm{~m}$ with generally two water inflows between 21 and $45 \mathrm{~m}$ depth in the altered cracked zone. After drilling, except the Hangbanou F10, the other nine drilling have flow rates higher than $10 \mathrm{~m}^{3} / \mathrm{h}$ which made allowed drilling.

The results from the boring work in terms of flow rates are presented in Table 3.

At the end of the boring work, the main objective is to increase drilling flows by widening the diameter of confirmed drilling. The analysis of this table shows that excepting the Sogo F4 borehole, where the flow of the confirmation survey $\left(22 \mathrm{~m}^{3} / \mathrm{h}\right)$ dropped to the bore $\left(12.3 \mathrm{~m}^{3} / \mathrm{h}\right)$, the remaining eight showed flow increase. Moreover, the F7 drillings of Dagahoho, Sohèdji F5 and F1 of the Cola Base 1 exhibited an increase of $100 \%$ on average of their flow after boring. For F2 drilling of Cola2 Base, F3 of Aglamidjodji, F8 of Dagahoho 2 and F9 of Kpapkassa failed to double the flow of the borehole survey. Nevertheless, there was an increase of $50 \%$ in average. Only the flow rate of the Monkpa F6 borehole remained more or less constant from the borehole survey $\left(10 \mathrm{~m}^{3} / \mathrm{h}\right)$ to $10.5 \mathrm{~m}^{3} / \mathrm{h}$.

Statistical analysis is made and presented in Figure 9. In the diagram, it is noted that the drilling technique in the crystalline basement area allowed 100\% or more increasing flow rate over $34 \%$ in drilling. In addition, $50 \%$ of flow rate increase is observed over $44 \%$ in drilling. However, the boring technique had no effect on $11 \%$ of the boreholes. Furthermore, $11 \%$ of the boreholes experienced a drop in flow as a result of drilling.

With these results, we can conclude on the following:

- The ERT allows drilling to be implemented with a success rate of $100 \%$ in the basement rocks with good flow rates;

- The drilling technique in crystalline basement rocks, it is possible to increase from 50 to $100 \%$ the flow of bore.

However, the distribution of the groundwater resource is spatially non linear in the context of crystalline basement rocks otherwise, similar flows should be obtained in the various drillings.

\section{Discussion}

The geophysical prospecting method adopted in this work has identified the different interesting structures for the positioning of future water points in the study area. Indeed, the high definition imagery of the ERT of the subsoil 2D of

Table 3. Comparison of drilling flow after confirmation survey and boring.

\begin{tabular}{cccccccccc}
\hline Forage & F1Ba1 & F2Ba2 & F3Aj & F4Sg2 & F5Sj & F6Mp & F7Dh1 & F8Dh2 & F9Ks \\
\hline $\mathrm{Q}_{\mathrm{CS}}\left(\mathrm{m}^{3} / \mathrm{h}\right)$ & 10 & 12.3 & 15.3 & 22.6 & 24 & 10 & 35 & 13 & 11 \\
$\mathrm{Q}_{\text {boring }}\left(\mathrm{m}^{3} / \mathrm{h}\right)$ & 25 & 15.5 & 20.4 & 12.3 & 51 & 10.5 & 85 & 17 & 16 \\
\hline
\end{tabular}




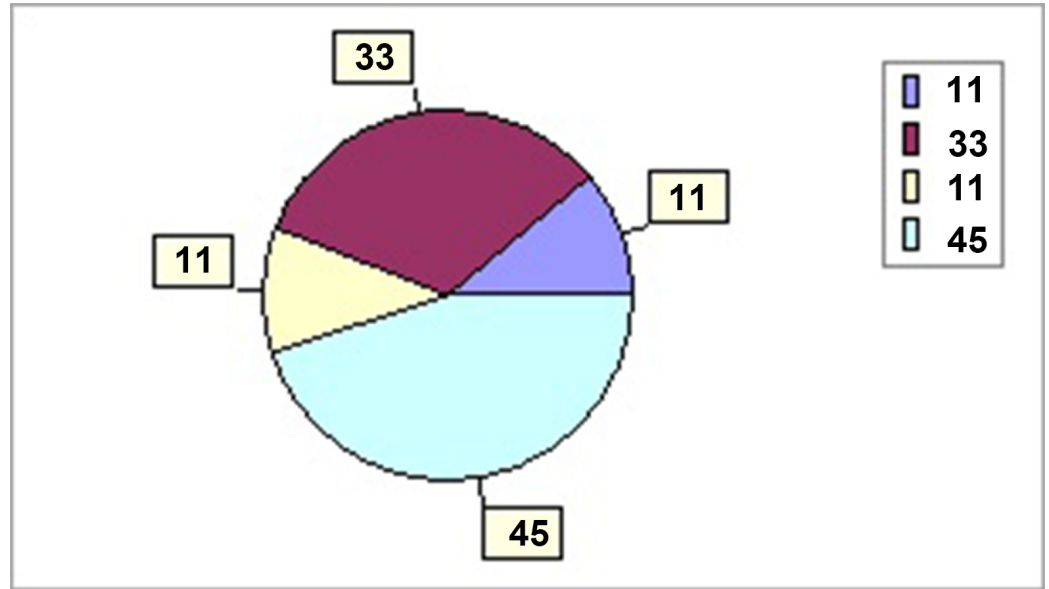

Figure 9. Diagram summarizing flow statistics after boring technique.

each of the ten (10) sites showed the presence of the conductive zones in the resistant base. These zones probably correspond to fractures that are excellent flux-conductive. The observation and interpretation of the panels of the various profiles made, allows good location of the discontinuities zones and if necessary stakes is repositioned in order to maximize the success rate of drillings. A similar approach conducted by Vouillamoz (2003) in Moznmbique and Alle et al. (2018) in Benin in the basement area strongly recommended the use of ERT for improving the success rate in drilling implementation. With the ERT, we clearly see in $2 \mathrm{D}$ conductive zones in the resistant basement rocks, which show the lateral extension of these discontinuities, and the thickness of the crack-alteration zone as well as the fractured zones which are the groundwater circulation corridors. The knowledge of these elements contributes to precise implantation of boreholes. However, the actual hydrogeological characteristics of each site can only be obtained through the execution of mechanical survey. With the mechanical or confirmation survey, one obtains punctual and local information from the implanted point. This makes it easier judgment of the reliability of the implantation studies.

Thus, the results of the drilling of the ten drill holes implemented allowed the calibration of the results of the geophysical prospecting campaign by the ERT. It appears from mechanical survey that the average thickness of alteration in the study area is $5 \mathrm{~m}$ against $11 \mathrm{~m}$ at the prospection. As for the limit of the fissured-altered zone and the fractured base, it is not well perceived during the geophysical prospection. However, there are well visible during drilling and allow clear geological structure of the divers soils. The thickness of both seems to coincide with that obtained during the survey ( $25 \mathrm{~m}$ on average). At the end of the drilling, the success rate is $100 \%$, rate obtained for the first time in basement area with very good flow rates $\left(10\right.$ to $35 \mathrm{~m}^{3} / \mathrm{h}$ ) never obtained in the past. In addition, with the bore technique used for the very first time in the study area, the flow doubled (from 35 to $85 \mathrm{~m}^{3} / \mathrm{h}$, i.e. an increase of more than $100 \%$ in the flow rate) in Dagadoho for instance. It should be noted that these flow rates come 
solely from cracked-fractured zones, that is to say without the contribution of the alteration which constitutes the storage zone and which would contribute to the flow according to Descloitres et al. (2008), Soro et al. (2017) and Alle et al. (2018). It is retained that in Savalou and surrounding area, the water coming from the alteration in insignificant because of low thickness ( $5 \mathrm{~m}$ on average). The small thickness of the alteration facilitates the observation of the fissured fractured zone in $2 \mathrm{D}$ with the ERT, thus the implantation point of the drillings.

\section{Conclusion}

At the end of the present study, it appears that the geophysical investigations by the ERT allow identifying and defining the characteristics (thicknesses of alteration, depth of the fissured horizon) of the aquifers for drilling implementations with $100 \%$ of successful rate during drilling survey. In addition, the borehole technique also significantly improved and achieved unprecedented flows in the study area. In fact, the borehole has increased the flow obtained at confirmation surveys from $50 \%$ to $100 \%$ and has mobilized a cumulative flow of $252.7 \mathrm{~m}^{3} / \mathrm{h}$ for the nine new boreholes for water supply of the city of Savalou and surrounding. Thus, the geophysical prospection by the ERT and the drilling works by the boring technique remain complementary methods that help reducing water chore for the populations in the crystalline basement zone.

We intend to continue the investigations by carrying out long-term pumping on each of the nine boreholes in order to determine the hydrodynamic parameters of these fractured aquifers captured.

\section{Acknowledgements}

This study was carried out thanks to the project "Emergency measure for the reinforcement of the drinking water supply system of the city of Savalou" financed by Benin Republic. The contents of this paper are the sole responsibility of the authors who would like to thank and acknowledge the anonymous instructors for their criticisms, comments and suggestions that contributed to the improvement of this document.

\section{Conflicts of Interest}

The authors declare no conflicts of interest regarding the publication of this paper.

\section{References}

Achidi, J. B., Bourguet, L., Elsaesser, R., Legier, A., Paulvé, E., \& Tribouillard, N. (2012). Carte hydrogéologique du Benin, carte de l'ensemble du territoire a l'échelle 1/500 000 Notice Explicative Version Finale (pp. 95).

Adissin-Glodji, L. (2012). La zone de cisaillement de Kandi et le magmatisme associé dans la région de Savalou-Dassa (Bénin): Etude structurale, pétrologique et géochronologique. Sciences de la Terre. Saint-Étienne, France and Bénin: Université Jean Monnet-Saint-Etienne and Université d'Abomey-Calavi. 
Affaton, P. (1987). Le bassin des voltas (Afrique de l'ouest): Une marge passive du protérozoïque supérieur tectonisé au panafricain (Vol. 2. pp. 426-449). Thèse d'état, France: Université d'Aix-Marseille.

Alle, I. C., Descloitres, M., Vouillamoz, J. M., Yalo, N., Lawson, F. M. A., \& Adihou, A. C. (2018). Why 1D Electrical Resistivity Techniques Can Result in Inaccurate Siting of Boreholes in Hard Rock Aquifers and Why Electrical Resistivity Tomography Must Be Preferred: The Example of Benin, West Africa. Journal of African Earth Sciences, 139, 341-353.

Baltassat, J. M., Maurice, B., \& Reninger, P. A. (2017). Tomographies de résistivité électrique appliquée à l'implantation d forages AEP sur sites à Mayotte (71 p.). Rapport Final.

Boukari, M. (1982). Contribution a l'étude hydrogéologique des régions de socle de l'Afrique intertropicale: L'hydrogéologie de la région de Dassa-zoumè (Benin). Thèse, Dakar|’ ‘'Senegal: Université de Dakar.

Descloitres, M., Ruiz, L., Sekhar, M., Legchenko, A., Braun, J. J., Mohan Kumar, M. S., \& Subramanian, S. (2008). Characterization of Seasonal Local Recharge Using Electrical Resistivity Tomography and Magnetic Resonance Sounding. Hydrological Processes, 22, 384-394. https://doi.org/10.1002/hyp.6608

Drouart, E., \& Vouillamoz, J. M. (1999). Alimentation en eau des populations menacées, 1999 Hermann, éditeurs des sciences et des arts, 293 rue Lecourbe, 75.15 Paris.

INSAE ou Institut National de la Statistique et de l'Analyse Economique (2016). Effectifs de la population des villages et quartiers de ville du Bénin rapport final (RGPH-4, 2013) (83 p.).

Kamagaté, B. (2006). Fonctionnement hydrologique et origine desécoulements sur un bassin versant de milieu tropical de socle au Bénin: Bassin versant de la Donga (haute vallée de l'Ouémé). France: Université de Montpellier.

Maliki, R., \& Tamadaho, M. (2012). Plan Directeur Eau-Tome V.4.8 Plan d'Investissement Actualisé AEP Savalou élaboré dans le cadre du projet Plan Directeur Eau Soneb/Bénin (54 p.).

Roques, C. (2013). Hydrogéologie des zones de faille du socle cristallin: Implications en termes de ressources en eau pour le Massif Armoricain (285 p.). Thèse de doctorat, Rennes', |France: Université de Rennes.

Soro, D. D., Koita, M., Biaou, C. A., Outoumbe, E., Vouillamoz, J. M., Yacouba, H., \& Guerin, R. (2017). Geophysical Demonstration of the Absence of Correlation between Lineaments and Hydrogeologically Useful Fractures: Case Study of the Sanon Hard Rock Aquifer (Central Northern Burkina Faso). Journal of African Earth Sciences, 129, 842-852.

Vouillamoz, J. M. (2003). La caractérisation des aquifères par une méthode non invasive: Les sondages par résonance magnétique protonique (236 p.). Thèse de doctorat, Paris, France: Université Paris Sud-Paris XI.

Vouillamoz, J. M., Lawson, F. M. A., Yalo, N., \& Descloitres, M. (2015). Groundwater in Hard Rocks of Benin: Regional Storage and Buffer Capacity in the Face of Change. Journal of Hydrology, 520, 379-386. https://doi.org/10.1016/j.jhydrol.2014.11.024 